\title{
THE COATLICUE'S STATE IN THE MIXQUIAHUALA LETTERS: A POSTMODERN INTERPRETATION ON HOW TO REACH THE MESTIZA CONSCIOUSNESS
}

\author{
Mariela Aguilar \\ University of California, Santa Barbara, USA
}

\begin{abstract}
During the Chicana Literary Renaissance of the 1980s, Chicana writers-influenced by the Third World Feminist Movement-revealed new forms of representation of the Chicana experience. While concentrating on the subversive reading of the subject-object duality in Ana Castillo's novel, The Mixquiahuala Letters (1985), Gloria E. Anzaldúa's theory of the mestiza consciousness is also reviewed. Castillo represents the mestiza consciousness through her protagonist in a process of self-discovery through the reflection of autohistoria-teoria within the forty letters. The dichotomies of patriarchal ideologies that divide her from the Other are examined through the Coatlicue State, as inflected by such writers such as Julio Cortázar, Anaïs Nin and Miguel de Cervantes. Castillo creates a postmodern hopscotch style novel in which the reader is fundamental to the subversive interpretation of the three reading options (the conformist, the cynical, and the quixotic).
\end{abstract}

Keywords: The Mixquiahuala Letters, Gloria E. Anzaldúa, The Mestiza Consciousness, Coatlicue State, Autohistoria-teoria, Postmodern Writings.

\section{EL ESTADO DE COATLICUE EN THE MIXQUIAHUALA LETTERS: UNA INTERPRETACIÓN POSTMODERNA DE CÓMO LOGRAR LA CONCIENCIA MESTIZA}

\section{RESUMEN}

La literatura escrita por chicanas en su renacimiento durante la década de 1980 -influida por un movimiento tercermundista feminista- reveló nuevas formas de representación para la experiencia de la chicana. Al concentrarnos en una lectura subversiva de la dualidad entre sujeto-objeto en The Mixquiahuala Letters (1985) de Ana Castillo, también nos fijamos en la teoría de Gloria Anzaldú sobre la conciencia mestiza. Castillo representa tal conciencia mestiza a través de su protagonista en un proceso de auto-descubrimiento mediante la reflexión conocida como la auto-historia-teoría dentro de las 40 cartas. Las dicotomías de las ideologías patriarcales que la dividen del Otro también se examinan mediante el Estado Coatilicue de acuerdo a la influencia de escritores como Julio Cortázar, Anaïs Nin y Miguel de Cervantes. Castillo crea una novela estilo rayuela de tipo postmodernista en la cual el lector es fundamental para la interpretación subversiva de las tres opciones de su lectura (conformista, cínica y quijotesca).

Palabras clave: The Mixquiahuala Letters, Gloria E. Anzaldúa, la conciencia Mestiza, estado de Coatlicue, Autohistoria-teoría, escritura postmoderna.

DOI: https://doi.org/10.25145/j.recaesin.2020.81.12

Revista Canaria de Estudios Ingleses, 81; November 2020, pp. 181-192; ISSN: e-2530-8335 
The work of mestiza consciousness is to break down the subject-object duality that keeps her a prisoner and to show in the flesh and through the images in her work how duality is transcended. The answer to the problem between the white race and the colored, between males and females, lies in healing the split that originates in the very foundation of our lives, our culture, our languages, our thoughts. A massive uprooting of dualistic thinking in the individual and collective consciousness is the beginning of a long struggle, but one that could, in our best hopes bring us to the end of rape, of violence, of war.

Gloria E. Anzaldúa

Borderlands/La Frontera: The New Mestiza

As the first modern novel, El ingenioso hidalgo Don Quijote de la Mancha $(1605,1615)$ has left a cultural legacy that has transcended temporal and geographical boundaries. It is no surprise postmodern writers are influenced by the novel's intertextuality in a literary quest to maintain a dialogue between the novel and other texts or authors; modern or otherwise. If what stands out in the Miguel de Cervantes de Saavedra's novel is the ambivalent identity of the modern man in his main character, for the postmodern world Don Quijote is a symbol of resistance, enabling us to imagine other worlds in search of freedom and justice. Thus, for the Chicano/a writer Don Quijote represents a modus operandi for liberation - found when the Chicano community becomes conscious of its colonized history. The quijotization of Teresa's life, in Ana Castillo's novel The Mixquiahuala Letters (1987), is what this paper seeks to analyze to demonstrate how being quijotized enabled the protagonist to transform her personal experiences into a retrospective life lesson at the age of 40 . The trope of quijotization in The Mixquiahuala Letters (1985) could be better understood as what Gloria E. Anzaldúa termed the mestiza consciousness. For this reason, our study will highlight how the intertextuality in this novel under the influence of Cortázar's hopscotch style, as evidenced in Rayuela (1963), demonstrates the process Teresa undergoes to reach the mestiza consciousness to define her identity.

Although published in different periods, Don Quijote and The Mixquiahuala Letters share similar aspects in the temporal context exhibited in its plots and characters' constructions. First, it is important to highlight what Zygmunt Bauman has defined as modernity and its consequent postmodernity. Bauman clarifies that order and chaos are creations of the modern world, due to its insatiable task of giving order and classification to the world. However, he contends that this task's result has created a sense of ambivalence because the function of classifying and categorizing has imposed an unsustainable order. Imposing order is:

[...] a fight of determination against ambiguity, of semantic precision against ambivalence, of transparency against obscurity, clarity against fuzziness. Order is a concept, as a vision, as a purpose could not be conceived but for the insight into the total ambivalence, the randomness of chaos. Order is continuously engaged in the war of survival. The other of order is not another order: chaos is its only alternative. The other of order is the miasma of the indeterminate and unpredictable. The other is the uncertainty, that source and archetype of all fear. (Bauman 6-7) 
Therefore, the idea about the order imposed by the modern world, considering those designs of a ruling by the sovereign state, is nothing more than a manipulation strategy, proving that language played an indispensable role in categorizing and classifying to separate and exclude. According to Bauman, intolerance is one of the most notable symptoms of modernization, which "calls for the denial of rights, and the grounds, of everything that cannot be assimilated- for de-legitimation of the other" (8-9). The modern state's purpose is to exclude the Other and erase its citizens' differences to form an assimilated and homogenous entity. It comes as no surprise that the postmodern era calls for change to respect and honor those differences by searching for other ways of seeing and thinking beyond the modern age's binary order. Bauman clarifies that although these two epochs are not so different, and the Other continues to be marginalized, the postmodern era contains a new determination: "to guard the conditions in which all stories can be told, and retold, and again told differently" (244). Since the creation of the new modern state divided the world by adopting ideologies and practices that did not tolerate the ambivalent, the postmodern world to observe and respect these differences is an act of consciousness that opens the possibility to imagine another world where everyone is accepted.

El ingenioso hidalgo Don Quijote de la Mancha and The Mixquiahuala Letters are two creations of the modern and postmodern eras that expose humans' ambivalence in the face of the classifying power of the sovereign state. As mentioned above, these two novels, although conceived in different epochs, have a common denominator: quijotization as a way of life. On the one hand, these novels showcase the feelings of disconformity their characters experience toward the order imposed by the societies they inhabit; while at the same time, both books describe what the process of accepting ambivalence is like. In Transnational Cervantes, William Childers points out that what is common between Cervantes, as a writer of the first modern novel, and the Chicano writers of the postmodern era is the concept of "internal colonialism" (4). Both Cervantes and Castillo are members of sovereign societies in whose neocolonialist ideologies perpetuate heteronormative hegemony, creating a fragmented reality between a sovereign and subordinate society. According to Childers, internal colonialism in Spain started when the monarchy began the conquest and colonization of the new world. Although this colonization was external, Childers clarifies that this imperialist project was also internal. Domestically, the approach of internal colonization fell unto the ethnic-religious minorities of Jews and Arabs by imposing centralized authority under a Christian's power. Childers concludes that the creation of the nation-state had as its first step the implementation of internal colonization. As a result, all those cultures that did not assimilate to the dominant culture experienced the ambiguity of not belonging: "[...] their own culture was rendered valueless, except as a sign of inferior status or of defiant resistant; yet they were not accepted as full belonging to the new culture imposed upon them, and became instead the object of vigilance, scrutiny, and suspicion" (Childers 7).

As in Spain, the United States, as a sovereign nation-state, also contains an ideology similar to the former Spanish empire. The former, like the latter Spain, also has a long history of internal colonization in which cultural minorities have been monitored and discriminated against for not assimilating to Anglo-Saxon cultural 
hegemony. In this regard, the Mexican American, Chicano, and Latino/a/x minority are the product of double colonization that continues to relegate them to a status of inferiority to maintain power over them. Both Cervantes and Castillo managed to observe how this hegemonic power, which continues to fragment the world, affects their protagonists' identity and sense of belonging.

The United States is a country made of immigrants; therefore, its society is multiethnic and multicultural, and the Chicano culture has been one at the forefront of resistance. This group has been classified throughout its existence, under Spanish and American forces, as being inferior and predestined to subjugation. However, the Chicana/o/x and Latino/a/x communities have shown to be one of the groups that have imposed the most resistance on the nation-state. Chicanas have demonstrated that internal colonization is not only the product of the nation-state but of any entity that seeks to impose their ideologies onto the Other. As a result, Chicana writers such as Gloria E. Anzaldúa and Ana Castillo have responded strategically through art mediums, such as literature, to offer those experiencing the exclusion caused by ambivalence the tools to accept the fragmented parts of our identities to continue healing and resisting to make other worlds possible.

Chicana feminist literature has evolved over the last quarter of the 20th century, focusing on the critical literary output of women's traumatic experiences living between borderlands- both physical and psychological. Chicana feminists have also highlighted the impacts the outer social, cultural, economic, and political measures, laws, and policies of the patriarchal and heteronormative Nation State have had on Women of Color's livelihoods. The breakup of a nationalist Chicano literature, influenced by new trends, both feminist and postmodernist, brought forth new forms of representation and interpretation of the Chicana experience and identity. The formulation of a new identity for Chicanas, free of cultural prejudices, has manifested itself through a subversive reading of breaking the duality paradigm between subject-object. The objective her is an interpretation of Castillo's novel as a subversive text that contains elements of quijotization. The Mixquiahuala Letters is a novel that confronts the dualities perpetuated by the order imposed in the social construction of gender and race, made visible by the Coatlicue State and the concept of the Other, to create a collective consciousness to redefine the identity of Chicanas through the petite histoire of two mestiza women, Teresa and Alicia.

In analyzing The Mixquiahuala Letters, the theory proposed by Anzaldúa in Borderlands/La Frontera: The New Mestiza (1987) on how to attain the mestiza consciousness and forge a new destiny free of discriminatory/oppressive dualities, will help reinterpret the personal experiences of Teresa. As a Chicana writer, Castillo takes her protagonist into a retrospective self-discovery process to help her reach the mestiza consciousness through the act of writing and self-reflection in the 40 letters that compose the novel. It will later be explained how the act of writing exerts a highly significant power in Teresa's life, as an author(ity), narrating her own story, or autohistoria. In this manner, Castillo deconstructs the dichotomies of the patriarchal ideologies within the Mexican and American cultures to set her protagonist free from the traumas that divide her from the Other, in this case, Alice, her life-travels companion. Another part of the objective is examine how the influence of writers 
such as Miguel de Cervantes, Julio Cortázar, and Anaïs Nin, along with other postmodern elements, enabled Castillo to construct a novel in which the reader is fundamental to the interpretation of the letters in its three optional readings.

In the introduction to the third edition of Borderlands/La Frontera: The New Mestiza (2007), Castillo, one of the voices that make up this introduction, explains that the act of writing allows the writer to enter a meditative state for introspection. Gloria E. Anzaldúa has identified this as the Coatlicue State, or Coatlicue's heritageimperative to understand and deal with "opocisión e insurrección," a state in which an individual understands pain is inevitable for change to happen (Anzaldúa, 73). In the Coatlicue state, the mestiza ponders the contradictions-or ambivalence, as Bauman calls it, of living between two cultures and being the recipient of societal ideologies that oppress both women and those who live alternative lives to the periphery of the hegemonic and heteronormative dominant culture. By confronting these oppositions, the mestiza can attain liberation to forge her destiny and identity free of all forms of oppression imposed by nation-state. However, reaching the resurrection point, or the mestiza consciousness, is a painful and fragmentary process. Through this meditation state, Teresa begins a journey through the Coatlicue State to experience the quijotization of her life by learning how to deal with the ambivalence of being Mexican American or a Chicana. The active reader soon realizes that the only possible way to interpret this journey through Castillo's is through the three postmodernist readings. Castillo limits the reader to choose one of the three imposed paths: the conformist, the cynic, and the quixotic. Nevertheless, no single reading path captures the complete life or totality of Teresa's experiences. For this reason, to comprehend the way of life that Teresa carries out in the quixotic path, the reader needs to understand the experiences lived by the main characters in the conformist and cynical trajectories.

Several critical studies have classified The Mixquiahuala Letters as an epistolary novel. However, it is essential to emphasize that Castillo transgresses this genre's limits. Epistolary novels are generally classified by the narration of letters written by the characters, but Castillo uses letters and reflections, memories, poems, stories, dreams, and even myths told through Teresa, the only author of the text's letters. Besides, an epistolary novel's structure consists of the compilation of an epistolary exchange between the sender and the recipient, emphasizing different views and perspectives on the narrated events through dialogue and plot development. For this reason, The Mixquiahuala Letters has been classified as an epistolary novel due to the exploration of lived and shared experiences between two women, Teresa and Alicia. Yet, the letters' subjective authorship has been ignored, as the reader can only read those letters penned by her. More importantly, the text does not provide evidence to confirm that Alicia, the recipient of the letters, exchanges written correspondence with Teresa. For example, in letter number three, Teresa writes:

Each time, a few days passed, a week, and i'd receive a copy of Neruda's poetry, you, a ten-page letter of self-recrimination, you, a long distance call in the dead of the night, i, a hand-painted postcard, you, a copy of the Diary of Anaïs Nin, i, a pair of copper earrings from your recent collection, you, seven poems fresh out of the typewriter, i, a ceramic brooch. (Castillo 23) 
Thus, throughout the forty self-styled letters that make up the novel, the reader can examine only the letters written by Teresa. These letters in exchange allow the reader to come to know the interiority of Teresa's being because her reflections contrast and compare her life through the life and actions of Alicia and other secondary characters. The influence of postmodernist literary tendencies is why this epistolary novel transgresses this genre's frames since the mixture of genres and intertextuality, such as the reference to other literary texts or writers, has been widely displayed.

It is essential to consider the novel's paratexts as a postmodernist technique employed by Castillo as critical pieces to decipher its content within the story. According to Gerard Genette, paratexts-such as; captions, dedications, and selfreferentiality-are crucial elements for interpreting a postmodernist literary text (15). The influence of writers such as Anaïs Nin, Julio Cortázar, and Cervantes are elements that demonstrate how Castillo uses their influence to guide the reader on the paths that will lead Teresa to redefine her identity.

On the one hand, the caption attributed to Anaïs Nin shows the rupture in the practice of patriarchal ideologies that Castillo wishes to implement to lead her main character to develop the mestiza consciousness. The caption quoting Nin states: "I stopped loving my father a long time ago. What remained was the slavery to a pattern"-evidence shows, in a very intimate way, the relationship of subordination that exists between the social construction of binary gender roles, male and female, more specifically between father and daughter or men and women. This subordination, subject vs. object, is well outlined in the three reading trajectories Castillo references in her novel's intertextuality. Throughout the forty letters, it is clear that Teresa lacks a father figure while, and in her love life, she or her romantic partners continue to end their romantic relationships. The lack of the male authority presence represents a symbol of approval to corroborate the value of the female independence.

For this reason, the relationship between men and women is a subtheme that helps Teresa reflect on her life: what it means to be a woman, and its implications in both cultural societies-American and Mexican-to which she belongs. Judith Butler, in Cuerpos que importan: sobre los limites materiales y discursivos del 'sexo' (2010), examines how the social construction of gender and sex have kept patriarchy, or the Father's Law, as a social discipline, which has created a phallocentric discourse that highlights the superiority position of the male over the feminine or abject as a subject of inferiority (89-90). As a queer theorist, one of Butlerian criticism's most important objectives is to question the heteronormative discourses of the Father's Law to offer new alternatives to create a supportive and inclusive society of bodies that this law has marked as intelligible or abject. Butler argues that to accomplish this,

La tarea consiste en reconfigurar este 'exterior' [lo marginal] necesario como un horizonte futuro, un horizonte en el cual siempre se estará superando la violencia de la exclusión. Pero también es igualmente importante preservar el exterior, el sitio donde el discurso encuentra sus límites, donde la opacidad de lo que no ha sido incluido en un determinado régimen de verdad cumpla la función de un sitio 
desbaratador de la impropiedad o la impresentabilidad lingüística e ilumine las fronteras violentas y contingentes de ese régimen normativo precisamente demostrando la incapacidad de ese régimen de representar aquello que podría plantear una amenaza fundamental a su continuidad. (Butler 9l)

In this case, Nin's intertextuality and her diary provide Teresa the opportunity to re-evaluate this regime to provide a new horizon to free the female body from the bondage of inferiority. As stated before, imposing order on the modern world, social constructions such as patriarchy categorized society into dualities, thus creating a state of ambivalence and confusion for all those who did not fit into these classifications.

Therefore, The Diary of Anaïs Nin (1966), like the caption, is key to understanding Castillo's literary text's subversion and, consequently, the letters. In the introduction to the diary, Gunther Stuhlman states that the diary is

[...] more than a mere record of her days, her conversations, her encounters, though she captures them with vivid immediacy. The diary is the log of her journey through the labyrinth of the self, of her effort to find, and to define, the woman Anaïs, the real and the symbolic one who balances "between" action and completation, involvement and self-preservation, emotion and intellect, dreams, and reality, and who sometimes despairs of ever reconciling these disparate elements. (Stuhlman vii)

As a result, The Diary of Anaïs Nin appeals to Teresa, as an artist, a pretext to write the letters in a diary entry style in order to reflect on her own experiences and encounters with the Other and to redefine her own identity and re-discover herself in the maze of life as a mestiza woman. Simultaneously, the same diary is mailed to Alicia, the adventure companion, so that Alicia can free herself from the law of the Father that governs and affects both their lives. In this way, like Nin, Teresa has to choose which experiences to include in her letters and what to write about such experiences. This is how Castillo's hopscotch game subversively hides her novel's many interpretations that the reader has to decipher.

The Mixquiahuala Letters manages to show the practical experience of “oposición e insurrección” through Coatlicue's heritage aided by the hopscotch's literary game, first experimented by Cortázar in his famous novel, Rayuela. This is another way that Castillo subverts elements of the epistolary genre since the author does not provide a clear beginning, plot, or outcome. However, what Castillo offers is an unlimited or open text as the final fate of his characters is unknown. This is not only due to Castillo's dedication of her novel to "[...] The master of the game Julio Cortázar" (6) but to the imitation of the structural style of the Cortazar's novel. Like Rayuela, in The Mixquiahuala Letters, Castillo interacts with the readers by making them an active participant in the text. Like Rayuela, the reader is confronted with choosing one of the three possible paths in which to read the book. In Castillo's novel, the three options are the conformist, the cynic, or the quixotic. In structuring the text in this way, the reader encounters an endless novel, since none of the routes include the reading of all forty letters that compose it (unless the reader reads letter 1 to letter 40 in order, which is in itself another reading among the almost infinite 
readings). Simultaneously, the letters are atemporal, as none of them include a date, but fragmentally they narrate adventures or happenings of the last decade of life of the protagonists. More than a compliment to the master of the game, in order not to offer a traditional reading of the novel, Castillo also offers a critique of it since his novel does not critically include the abject bodies of those who Butler and Anzaldúa reference to create a third space of tolerance while confronting the dichotomies presented by the Law of the Father. Although in Rayuela Cortázar attempts to project "the dramas of the human condition" by exchanging incomprehensible and unbearable reflections made by his male characters, Ana María Simo proposes that this is a vertical cutting resource of a sexist society (65). By presenting a reading from a feminist perspective, Castillo is not merely imitating Cortázar but creates her own game to represent commonly marginalized women's stories. Therefore, navigating the three reading routes proposed by Castillo is essential to discover how the structure of the text reflects how Teresa is transitioning from the Coatlicue's State to finding her way into the mestiza consciousness by seeking a greater totality and complexity.

As previously mentioned, the Coatlicue State is not a pleasant experience, as individuals can experience painful events in this state. Entering the serpent state is like a "confrontation with the soul" (Anzaldúa, 54). However, entering this state is not always voluntary, as the Coatlicue State can manifest itself in women's and men's lives without warning. Anzaldúa clarifies the following:

We need Coatlicue to slow us up to that the psyche can assimilate previous experiences and process the changes. If we don't take the time, she'll lay us slow with an illness, forcing us to "rest." Come, little green snake. Let the wound caused by the serpent be cured by the serpent. The soul uses everything to further its own making. Those activities or Coatlicue states which disrupt the smooth flow (complacency) of life are exactly what propel the soul to do its work: make soul, increase consciousness of itself. Our greatest disappointments and painful experiences-if we can make meaning out of them-can lead us toward becoming more of who we are. Or they can remain meaningless. The Coatlicue state can be a way station or it can be a way of life. (Anzaldúa 67)

That "illness" to which Anzaldúa refers to can provoke the Coatlicue State, and Teresa describes it in multiple letters as a "heartburn" (Letter 2 and Letter 21) and that "to be rid of it, i must create distance" (Castillo 64). The betrayal revealed in the cynic path's final letter-letter 38, is one of the denotations, or "illness" that leads Teresa to enter Coatlicue's State. Although the letter lacks a date and is atemporal, the estrangement between the two friends is caused by Alicia's betrayal of their friendship with Teresa's ex-partner (Vicente das Mortes). This is the denotation that leads Teresa to confront not only her friend but also her soul. As she faces this betrayal and estrangement with Alicia, Teresa draws on the memories of their previous experiences to create changes in her life. In this way, the beginning of the conformist, cynical, and quixotic routes make sense with Letter 38, which can only be read once along the three paths proposed by Castillo. The intimate friendship between Teresa and Alicia is the same one that leads her to (re)evaluate her life to get rid of the pain of the "heartburn" caused by Alicia's betrayal. 
The conformist and quixotic reading routes share the same opening letter, Letter 2 -a prosaic poem. It is noticeable that the (re)evaluation of Teresa and Alicia's friendship considers only the last ten years of their lives and their interactions with other men on both sides of the US-Mexico border. Teresa writes, "Finally we end the cesspool/twirl of our 20s / that will be remembered always [...]" to congratulate Alicia on her 30th birthday (Castillo 17). This letter gives insight into how these letters were written periodically and recollected to compose the novel. Meanwhile, in the opening letter to the cynical route, Letter 3, Teresa begins her (re)evaluation through her friend Alicia's figure. She recalls about their friendship: "We were not to be separated. A fine-edged blade couldn't have been wedged between our shared consciousness [...]" (Castillo 18). Therefore, the cynical route delivers and explains what caused the falling-out between Teresa and Alicia, which leads the protagonistnarrator to enter the Coatlicue State. The cynical option in Castillo's hopscotch reading game is the one that shows the balance of what can happen in the Coatlicue State. The closing letters of the conformist and quixotic routes-Letter 34 and Letter 1 , respectively-are possible demonstrations of how entering the Coatlicue State can help the mestiza navigate the contradictions imposed on her. However, if ignored, it can keep one stagnant in disconformity if a didactic meaning of traumatic or painful experiences is not evaluated.

Thus, from the image and memories of Alicia and other secondary characters, Teresa can generate a retrospective self-assessment of her being to reach the mestiza consciousness. In her introspection, Teresa codifies how the intersectionality of her ethnicity, gender, and class affect her political persona and her experiences as a woman of color, thus subjugating her to double oppression by the Law of the Father imposed by both cultures to which she belongs. In Letter 19, Teresa reflects on how "Destiny is not a metaphysical confrontation with one's self, rather, Society has knit its pattern so tight that a confrontation with it is inevitable" (Castillo 59).

The differences between Alicia and Teresa's physical and moral values and the treatment they both receive as women and transgressors of the cultural values rooted in Mexican and American patriarchal societies lead Teresa to experience that metaphysical confrontation with herself. In a letter detailing the first encounter of both protagonists, on a study abroad trip to Mexico, Teresa confesses: "I'm not certain what your first thoughts were of me, studying the dark newcomer from across the dining table" (Castillo 18). Ethnicity, and especially the differences of their skin color, is one of the elements that separates them. In Letter 13, Teresa acknowledges why she hated white men and women at some point in her life, as "Society had made them above all possessions the most desired. And they believed it" (Castillo 43). Alice, as a white-passing woman, did not inspire confidence in Teresa. Nonetheless, their friendship enabled Teresa the opportunity to learn more about herself: "not being [economically] comfortable, white or an only child made me less concerned with myself. i found sources to direct my anger / pointed at them / called them white/privileged / and unjust" (Castillo 44). Through the concept and figure of the Other, Teresa understands how ingrained hatred toward the unknown is the cause of division and violence against the Other. 
Despite what society claimed that made Teresa and Alicia different, the shared consciousness about gender and women's rights brought them together. Teresa, a young, married woman, awakens in Alicia the curiosity to understand how "... any woman of [her] generation could willingly commit herself to slavery", obviously referring to marriage (Castillo 32). A woman's enslavement into serving a man is what marriage symbolized for Alicia, a liberal young feminist. Therefore, when Teresa decided to travel alone in Mexico through colonial states such as Yucatán, Veracruz, Oaxaca, Hidalgo, and Puebla, she began to experience how her consciousness on gender roles made her a stranger where she felt more excluded in her ancestral motherland. For example, when traveling alone in this country and meeting several Mexican men and women, Teresa understood "how revolting we were, susceptible to ridicule, abuse, disrespect. We would have hoped for respect as human beings, but the only respect granted to a woman is that which a gentleman bestows upon the lady. Clearly, we're not ladies. What was our greatest transgression? We traveled alone" (Castillo 59). Undoubtedly, in a patriarchal country like Mexico, being a liberal woman does not mean having the agency of free will but "simply meant a woman who would sleep non discriminately with any man... liberal: trash, whore, bitch" (Castillo 73). These kinds of reflections, in the meditative state of the writing process, propel Teresa to subversively question how the dualities that the Law of the Father has imposed on society have enabled all the state-violence against women.

Undeniably, the analysis of The Mixquiahuala Letters subverts in its fragmentary structure a puzzle that requires an active reader willing to listen attentively to all the transformations the protagonist experiences. The explicit references made about Coatlicue in Teresa's letters indicate that Castillo wants its readers to understand the act of writing as a tool to make sense of the ambivalence in which Western societies thrive. By confronting the reader with three possible reading paths or options, and more as each letter is a story, the readers can infer that Teresa is taking an inventory. When Teresa states: " $i$ want to take my ghosts...confront them face to face, snarl at them, stick out my tongue, wiggle my fingers from the sides of my head, nya-nya" (Castillo 124), she is becoming the moldeadora, the shaper, and subject of her own life. In contrast to the conformist path, in which Castillo presents how society only values good women, the cynical way offers another perspective. In this path, where women are categorized as the treacherous or the bad woman for their free-spirited behavior, this can lead only to a third space-the borderlands, or the quixotic path. Both women and/or abject bodies can break alienating dichotomies of thought just as Anzaldúa delineates the mestiza consciousness. All the reading paths or options presented in the novel reveal different realities in the life experiences that make up Teresa's total-or at least close to it-identity as a Chicana woman. It is not surprising that the 40 letters represent her contradictions and come to terms with who she is as she writes her personal experiences and analyzes her life evolution.

As we have seen, what Castillo exhibits in her novel is the long Eurocentric and colonized traditions that continue to perpetuate the dichotomies that divide men and women to foster intolerance. Bauman believes that this strategy of imposing order to combat chaos has only achieved the creation of a state of ambivalence in which abject beings and cultures not assimilated to the hegemonic culture question 
their condition as marginalized beings. According to Bauman, the postmodern era has to accept that the order of chaos proposed by the modern era is unattainable because the ambivalence created in the excluded bodies is greater and highlights the dissatisfaction imposed by the status quo (251). Developing the mestiza consciousness to recognize the contradictions evoked during the Coatlicue State is what Castillo structures as a young Chicana woman's life experiences in search of identity.

The Mixquiahuala Letters, as an epistolary correspondence or diary, is a postmodernist and feminist hopscotch reading puzzle that proposes to create a third space or new horizon to include what the patriarchal nation-state has classified as abject beings. In this text's construction, Castillo has created a dialogue that requires an active reader to understand the contradictions that patriarchal cultures imposed in that abject body. The act of writing a narration of self-introspection demonstrates its cathartic powers to confront the ambivalence that fosters violence against that which is deemed inferior. As a shaman and quixotic writer, Castillo finds in writing a highly demystifying ability to confront the historical and symbolic power of the patriarchal system that continues to create dichotomies and foster divisions. Therefore, after her rift with Alicia, Teresa undergoes a personal transformation-under the Coatlicue State- leading the reader to better understand how change starts from within. To break down the dichotomies imposed by the Law of the Father, one must first learn to overcome the internal struggles and the effects of colonization that divide us from the Other. Much like Don Quijote and Teresa, the power to conceive a just world starts with the symbolic power of imagination.

REVIEWS SENT TO AUTHOR: 1-6-2020; REVISED PAPER ACCEPTED FOR PUBLICATION: 12-9-2020 


\section{WORKS CITED}

AnZaldúa, Gloria. Borderlands/La Frontera. The New Mestiza. $3^{\text {rd }}$ ed. Aunt Lute, 2007.

Aznar, Camón. Don Quijote en la teoría de los estilos. Talleres Tipográficos del Hogar Pognatelli, 1949.

Bauman, Zygmunt. Modernity and Ambivalence. Polity Press, 1991.

Butler, Judith. Cuerpos que importan: sobre los limites materiales y discursivos del 'sexo'. Paidós, 2010.

Castillo, Ana. The Mixquiahuala Letters. Anchor, 1992.

Childers, William. Transnational Cervantes. University of Toronto Press, 2006.

Creel, Bryant L. Don Quijote, Symbol of a Culture in Crisis. Ediciones Albatros Hispanófila, 1988.

Genette, Gerard. Paratexts: Thresholds of Interpretation. Cambridge UP, 1997.

Nin, Anaïs, Gunther Stuhlman. "Introduction." The Diary of Anaïs Nin, 1931-1955. Ed. \& Intr. Gunther Stuhlmann. Swallow, 1966. i-xiii.

Simó, Ana María, Jose Lezema Lima, Roberto Fernández Retamar, Mario Vargas Llosa \& Julio Cortázar. Cinco miradas sobre Cortázar. Ed. Tiempo Contemporáneo, 1968. 